\title{
Uluslararası Dengeler Çerçevesinde Osmanlı İmparatorluğu-Venedik Cumhuriyeti İlişkileri ve Sadrazam İbrahim Paşa (1523-1536)*
}

\section{Elvin Otman}

\section{$0 \ddot{z}$}

Kanunî Sultan Süleyman döneminin uluslararası siyasetinde belirleyici role sahip olan İbrahim Paşa’nın sadrazamlık döneminde Osmanlı İmparatorluğu ve Venedik Cumhuriyeti arasındaki diplomatik ilişkiler güçlendirilmiş ve Osmanlı'nın Habsburg İmparatorluğu ile siyasi, askeri ve ideolojik mücadelesinde Venedik Cumhuriyeti hem bir müttefik hem de bilgi akışını sağlayan bir istihbarat kolu olarak değerlendirilmiştir. Bu dönemde iki devlet arasında bir savaş vuku bulmamıştır. Ancak, 1532 Alaman Seferi sonrası Venedik'in Habsburg İmparatorluğu'na yakınlaşması, Osmanlı'nın da Venedik'e yaklaşımını da değiştirmiş; İbrahim Paşa Venedik yönetimini birçok kez ahidnâme şartlarına uygun olarak hareket etmek konusunda uyarmıştır. Dönemin Venedik belgelerinde, Venedik dostu olarak nitelendirilen Paşa’nın, sadaretinin son yıllarında Venedik'e karşı daha sert bir tutum sergilediği görülmektedir. Bu makale, iki devlet arasındaki ilişkilerin esasen değişen uluslararası dengeler çerçevesinde şekillendiği iddiasını taşımakta ve bu dönemde İbrahim Paşa’nın gerek uluslararası siyaseti kurgulayan, gerekse Osmanlı-Venedik ilişkilerini dengeleyen en etkili siyasi isim olduğunu saptamaktadır. Paşa'nın 1536'da ölümünü takiben, 1537'de Venedik'e bağlı Korfu Adası'nın kuşatılması ve Osmanlı-Venedik barışının bozulması bu savın kuvvetli destekleyicisidir.

\section{Anahtar Kelimeler}

İbrahim Paşa (s. 1523-1536), Venedik, Osmanl1-Habsburg rekabeti, Şarlken, Alvise Gritti, evrensel imparatorluk, Relazione.

\footnotetext{
Geliș Tarihi: 27 Haziran 2016 - Kabul Tarihi: 31 Ocak 2017

Bu makaleyi şu şekilde kaynak gösterebilirsiniz:

Otman, Elvin (2019). "Uluslararası Dengeler Çerçevesinde Osmanlı İmparatorluğu-Venedik Cumhuriyeti İlişkileri ve Sadrazam İbrahim Paşa (1523-1536)”. bilig - Türk Dünyası Sosyal Bilimler Dergisi 90: 137-160.

** Dr., Ankara/Türkiye

ORCID ID: https://orcid.org/0000-0003-3558-9567

elvinotman@gmail.com
} 


\section{Giriş}

Bu makalede İbrahim Paşa'nın sadrazamlık döneminde Osmanlı İmparatorluğu ile Venedik Cumhuriyeti arasındaki siyasi ve diplomatik ilişkilerin üzerinde durulacak, ayrıca Paşa’nın Avrupa devletleri ile yürütülen siyasetin kurgu ve uygulanmasında ne denli etkin bir rol oynadığı tartışılacaktır. Saptamalarımıza göre, Paşa’nın sadrazamlık döneminin son yıllarında, iki devlet arasında süregelen barış, büyük ölçüde Venedik'in değişen Avrupa siyasi konjonktüründe kendi bağımsızlık ve toprak bütünlügünü korumak adına izlediği zorunlu tarafsızlık politikası yüzünden zarar görmüş; iki devlet arasında gerilim artmıştır. Yapılan uyarılarla beraber, Paşa'nın Osmanl1-Venedik barışının korunması konusundaki kararlılığı, kendi sadrazamlık döneminde iki devlet arasında olağan deniz ve sınır çatışmaları dışında bir savaşa meydan vermemişse de ölümünden bir yıl sonra gerçekleştirilen Korfu Kuşatması iki devlet arasındaki ilişkileri ciddi bir biçimde değiştirmiştir. Osmanlı Devleti'nin Avrupa siyasetini derinlemesine anlamak açısından Osmanlı-Venedik ilişkilerinin ayrıntılı incelemesinin yapılması gerekliliği şüphesizdir. Bu bağlamda, İbrahim Paşa’nın izlediği siyasetin yeni bilgiler ışında uluslararası dengeler çerçevesinde yeniden değerlendirilmesi mevcut çalışmalara katkı sağlayacaktır. Çalışmamız, Osmanlı-Venedik ilişkilerinin, 16. Yüzyıl başlarında doruk noktasına çıkan Osmanlı-Habsburg rekabeti tarafından şekillendiği iddiasını taşımaktadır. Bu noktada, İbrahim Paşa’nın sadarete geldikten sonra gerek Venedik Cumhuriyeti gerekse Habsburg İmparatorluğu ve Fransa karşısında izlediği politika, kullandığı yöntemler ve yaklaşımları, değişen siyasi koşullara göre irdelenmiş, bunların Venedik kaynaklarındaki yansımaları incelenmiştir.

1523 yılında sadarete yükselen İbrahim Paşa dikkat çekici bir yaşam öyküsüne sahiptir. Paşa, Sultan Süleyman'ın Manisa'da geçirdiği gençlik yıllarından beri hizmetinde bulunmuş ve kendisiyle yakın bir dostluk kurmuştur. Şahincibaşı ve Has Odabaşı gibi Sultan'la yakın iletişimini sürdürebileceği görevler üstlenmiştir. Paşa aynı zamanda Sultan'ın en büyük şehzadesi Mustafa'nın da lâlâsıdır. Sultan üzerinde büyük etkisi olduğu vurgulanmakta gerek siyasi ve askeri planlamalarda, gerekse devlet yönetimi ile ilgili konularda Sultan ve Paşảnın beraber hareket ettiği bilinmektedir. İbrahim Paşa, Sultan Süleyman'ın pek çok teveccühüne mazhar olmuş, sadrazamlığını takiben kendisine bir saray yaptırılmıştır (Atasoy 1972). Sanat ve edebiyata düşkün olan Paşa, pek çok şair ve sanatçıya da hamilik etmiş, sarayı 16. Yüzyıl'ın en önemli siyaset ve kültür merkezlerinden biri haline gelmiştir (Tezcan 2004). 
Ancak, Sultan tarafından kendisine gösterilen bu yakınlık sayesinde Osmanlı müverrihlerinin kendisine makbul lakabını uygun gördüğ̈ İbrahim Paşa üzerine yapılmış araştırmalar oldukça sınırlıdır. Araştırmacılar tarafından en sık kullanılan H. D. Jenkins' in (1911) biyografik eserindeki bilgiler, T. Gökbilgin (1952: 908-915) ve F. Emecen (2000: 333-335) tarafindan Osmanlı kaynaklarıyla zenginleştirilmiştir. Bu çalışmalar Paşànın sadaret dönemi ve ölümü hakkında ayrıntılı bilgi içermekle beraber, İbrahim Paşa’nın Osmanlı siyasetinde oynadığı rolü etraflıca tartışmaktan uzaktır. Bu bağlamda yapılmış en kapsamlı çalışmalar ise E. Turan'a $(2007,2009$ : 3-36) aittir. Turan, İbrahim Paşa’nın kökeninden başlayarak, evliliğini, Osmanlı siyaseti içinde yükselişini ve bu siyaseti nasıl kurguladığını, dönemin Osmanlı ve Venedik kaynaklarını kullanarak ayrıntılı bir biçimde tartışmış; çalışmalarında Paşànın iç ve dış siyasette Sultan Süleyman'ın mutlak temsilcisi ve hatta alter ego ${ }^{1}$ su olarak yansıdığını vurgulamıştır (Turan 2009: 4). Turan'ın çalışmaları ise 1526 yılına dek olan gelişmeleri tartışmakta; özellikle Venedik ve diğer Avrupa devletleri ile olan ilişkilerde değişimlere sahne olan 1526 yılı sonrası dönemi kapsamamaktadır.

Bu çalışmada ise temel olarak 1529 yılından 1537 Korfu Seferi'ne kadarki süreçte Osmanl1-Venedik ilişkileri, Osmanl-Habsburg rekabeti çerçevesinde incelenecek; Osmanlı bürokrasisinin en önemli isimlerinden biri olan İbrahim Paşa'nın, 16. Yüzyılın uluslararası siyasetinin kurgulanmasında oynadığı etkin rol mevcut çalışmalarla birlikte, araştırmacılar tarafından nadir olarak incelenmiş Venedik kaynaklarının ışığında tartışılacaktır. Bu noktada, Venedik Cumhuriyeti ile süregelen barışı korumak konusunda büyük kararlılık gösteren Paşảnın temel motivasyonunun kaynaklarda belirtildiği gibi Venedik'e duyduğu kişisel sempatiden değil, dönemin uluslararası siyasetinin gerektirdiği yararlı ittifaklar prensibinden kaynaklandığı ortaya konacaktır. Çalışmamızın bir diğer katkısı da mevcut literatürden farklı olarak, Paşa’nın ve uyguladığı siyasetin Venedik kaynaklarında nasıl değerlendirildiğinin de yeniden bağlamlandırılması olacaktır.

\section{Venedik Dostu Sadrazam İbrahim Paşa}

İbrahim Paşa ve Kanunî Sultan Süleyman dönemi hakkındaki çalışmaların çoğunda Paşa’nın sadaret döneminde Venedik Cumhuriyeti'ne karşı dostane bir politika izlediği vurgulanmıştır. 1503 yılında neticelenen Osmanlı-Venedik savaşından sonra iki devlet savaş meydanında karşılaşmamış, Paşa'nın 13 yıllık sadaret döneminde de barış korunmuştur. Paşa, aynı zamanda, Os- 
manlı payitahtında yaşayan Venedik kökenlilere ve tüccarlara da ayrıcalıklar sağlamıştır (Jenkins 1911: 19). Araştırmalarda sıkça yer bulan bu durum döneme ait birinci el kaynaklarda da belirtilmiştir. Venedik elçisi Pietro Bragadin 1526 yılında Venedik Senatosu'nda okunan relazione ${ }^{2}$ sinde sadrazamı Venedik hükümetinin dostu olarak nitelendirmiştir (Alberi 1840-1855, 3: 103).

Venedik'e karşı duyduğu bu dostluğun sebebi olarak çoğunlukla Paşa’nın Venedik kökenli olması gösterilmiştir (Sanuto 1879-1903, 35: 259). Venedik dominyonu olan Parga'dan devşirilen İbrahim Paşa’nın köklerini asla unutmadığı düşünülmüştür. Sadrazamlığa yükseldikten sonra ailesini payitahta getirdiği ve Müslüman olan babasını Yunus ismiyle Epir sancakbeyi olarak görevlendirdiği bilinmektedir (Gökbilgin 1952: 908-915). Paşa, Türkçe dışında yabancı dil bilgisine de sahipti. Anadili, Slav dilinin bir lehçesiydi (Turan 2009: 6); Farsça, Yunanca ve İtalyanca da konuşabiliyordu. Bu da elçi ve tüccarlarla doğrudan iletişim kurmasına olanak sağlıyordu (Alberi 1840-1855, 3: 103). En yoğun olarak da Osmanlı payitahtında görev yapan Venedik diplomatlariyla temas kuruyordu.

İbrahim Paşa’nın, kendisinin sadarete yükseldiği yıl Venedik Doçu seçilen Andrea Gritti’nin oğlu Alvise ile de yakın teması vardı. Babasının elçilik görevi sırasında İstanbul'da bir Rum kadınla olan evliliğinden dünyaya gelen Alvise Gritti, Katolik evliliği dışında doğduğundan, Venedik yasalarınca, siyasi görevler dâhil, tüm veraset haklarından mahrum bırakıldığından, ailesinin ticari etkinliklerini sürdürerek kariyer edinmek amacıyla doğduğu şehre dönen bir Venedikliydi. Ticaretini yaparak zenginleştiği tahıl, tatlı şarap, baharat ve değerli taşlar sayesinde birçok Osmanlı bürokratıyla beraber İbrahim Paşa'nın da ilgisini çekmeyi başardı ve onunla yakın bir dostluk kurdu (Finlay 1984: 79). Rivayete göre, ismini kendisinden alan ve o tarihte Pera olarak anılan Beyoğlu ${ }^{3}$ semtinde bulunan sarayındaki meclislerde Venedikli tüccar ve diplomatlarla beraber sanatçıları ve diğer Avrupa devletlerinin temsilcilerini ağırlayan, onlarla ticari ve siyasi sohbetler yapan Gritti'nin kimi zaman sadrazamı ve hatta bizzat Sultan'ı da ağırladığı çağdaşlarınca vurgulanmıştır (Della Valle 1857: 19). Bu dostluk İbrahim Paşa'nın sadaret mührünü almasıyla bir başka boyut daha kazandı: Paşa kısa bir zaman sonra Gritti'yi siyasi danışmanı olarak görevlendirdi. Böylece Osmanlı'nın en yüksek bürokratının en önemli hizmetine bir Venedikli, hatta Venedik Sarayı’na en yakın kişi getirilmiş oldu. Bu kararın dönemin Osmanlı-Venedik ilişkilerine büyük etkileri olduğu düşünülmektedir. 
Venedik kaynaklarında Paşa’nın bu seçiminde, kendisinin siyasi tecrübesizliğinin etkili olduğu belirtilmiştir (Ramberti 1539: 21). Bilindiği üzere, İbrahim Paşa terfi geleneği takip edilmeksizin Rumeli Beylerbeyi ve sadrazam olarak atanmıştı (Peçevî 1980: 20), askerî ve siyasi tecrübesi ise oldukça sınırlıydı (Turan 2009: 30). Bu yükselişi hem Venedik temsilcilerinin hem de Osmanlı bürokrasisinin dikkatini çekmiş, Paşảnın liyakati sorgulanmıştı (Turan 2007: 184-188). Bu nedenle kendisine rakip olabilecek biri yerine, Osmanlı bürokrasisinde yükselme şansı olmayan bir isimle çalışmak istemişti (Ramberti 1539: 21). Gritti pek çok özelliğiyle de Paşa'ya benziyordu: yabancı dil bilgisi zengindi, Padova Üniversitesinde antik çă̆ siyasi düşüncesini, felsefesini ve hukukunu öğrenmişti; sanata ve edebiyata düşkün, dünya işleri ile ilgiliydi ve Venedikli kimliğini Osmanlı kimliği ile birleştirerek harmanlamışt1; güçlü ve gösterişliydi (Otman 2012: 132-134). Paşảnın kendisine olan güvenini ve teveccühünü Gritti de aktarmıştır. Bugün Venedik Devlet Arşivi bünyesinde saklanan, Gritti'nin Venedik Senatosu'na yazdığı mektuplarda Venedikli kendisini İbrahim Paşảnın tahayyül edilemeyecek derecede inayetine mazhar olan bir hizmetkârı olarak tanımlamış; 1526 yılında gerçekleştirilecek Macaristan Seferi'ne kendisinin de katılacağını belirtmiştir ${ }^{4}$.

İbrahim Paşa’nın, Gritti’yi siyasete kazandırmasının yanı sıra, Osmanlı bürokratları arasında kendisine rakip olabilecek adayları da sırayla devre dışı bıraktığı ve kendisine bağlı bir yönetici ekibi kurduğu da bilinmektedir. Sadarete yükseldikten sonra kendisine muhalefet eden iki önemli ismi, 3. Vezir Ferhad Paşa ve 2. Vezir Ahmed Paşảyı bertaraf eden Paşa, özellikle Ahmed Paşảnın Mısır'da çıkarttığı isyanı bastırarak büyük bir güç ve saygınlık kazanarak Sultan Süleyman'ın otoritesini temsil eden tek ve en mutlak güce dönüştü. Kendisine tevcih edilen Rumeli Beylerbeyliği ile imparatorluğun en büyük askeri birliğine komuta edecek olan Paşa (Turan 2007: 242), 1529 seferi öncesi serasker rütbesini de alarak adeta Sultan'ın tüm yetkilerini kendi bünyesinde toplamayı başardı. Güce ve gösterişe olan merakı, yabancı elçilerle doğrudan kurduğu iletişim ve otoritesi ile İbrahim Paşa, Sultan Süleyman'ı gerek devlet içinde gerek uluslararası zeminde yansıtan bir figür oldu. Elde ettiği gücün kullanımı konusundaki yaklaşımları ise bu gücün yegâne kaynağı olan Sultan tarafından Paşa'nın 1536'da idam edilmesine yol açacaktı. 


\section{Evrensel İmparatorluk Söylemi ve Venedik ile İlişkiler (1523-1532)}

Osmanlı bürokrasisinin en üst basamağına çok kısa bir sürede yükselen İbrahim Paşa’nın gerek Venedik’e gerekse diğer devletlere karşı izleyeceği siyaseti temel olarak şekillendirense 16. yüzyılın ilk yarısının genel siyasi yapısıydı. Evlilik ve veraset yoluyla Avrupa'nın nerdeyse yarısını kontrol altında tutan Habsburg İmparatoru Şarlken Avrupa’yı tek bir siyasi bayrak altında toplayarak Antik Roma İmparatorluğu’nu yeniden canlandırmayı hedefleyen bir siyaset belirlemişti (Rice vd. 1994: 125). Bu durum, diğer bağımsız krallık ve prenslikler için büyük bir siyasi tehditti. Alman prensleri Habsburg otoritesini tanımamakta ısrar ederken, Fransa Kralı I. François da Şarlken'e karşı Kutsal Roma İmparatoru olma mücadelesi vermekteydi. Bu iki büyük gücün, başta Venedik yayılmasını engellemek amacıyla müdahil oldukları İtalya Savaşları'nda kendi kozlarını paylaşmaya çalışması İtalya’yı savaş alanı haline getirmiş, Venedik dâhil diğer İtalyan devletlerini de kendi bağımsızlıklarını korumak adına sürekli saf değiştirdiği bir mücadeleye itmişti. Siyasi mücadelenin yanında Reformasyon hareketinin de ideolojik bir mücadele yarattığı Avrupa sistemi, bir anlamda yeniden inşa sürecindeydi. Bu süreç, milenyum kehanetleriyle de ideolojik bir zemin kazandı. Şarlken'in tüm Hristiyanların birleştireceği, Yahudi ve Paganların Hristiyanlığa döndürülerek Kudüs'ün yeniden fethedileceği ve İsa Mesih'in bin yılllı imparatorluğunun kuracağı beklentisi, bu söylemi yaratan, başta şansölyesi Mercurino di Gattinara olmak üzere, destekçileri tarafından Şarlken'e bağlı uyruklar arasında hızla yayıldı (Agoston 2011: 109, 134-135, Boone 2016: 30). Bu, aynı zamanda İmparatora siyasi meşruiyet de sağlayan bir unsurdu.

Bu ortamdan Osmanlı İmparatorluğu kendini soyutlamadı; aksine onu şekillendiren bir güç oldu. Sultan Süleyman, İslam Halifesi unvanının yanı sıra İstanbul fatihi atası Sultan Mehmed'in kullandığı Kayzer-i Rûm, Roma İmparatoru sanını canlandırıyor; Şarlken'in dünya imparatoru olma projesine Doğu'nun en büyük gücü olarak rakip oluyordu. Doğu sınırındaki Safevi rekabetiyle, tıpkı Avrupa'da ortaya çıkan Katolik-Protestan mücadelesine benzeyen bir Sünni-Şii mücadelesi deneyimleyen Osmanlı İmparatorluğu'nun genç sultanı pusulayı batıya çevirmişti. İbrahim Paşa'nın sadrazamlığında ise Şarlken'in emperyal politikasına benzer bir siyasi söylem kurgulandı. Roma İmparatorluğu’nun mirasına sahip olmasının yanı sıra, İslam topraklarının fatihi ve Müslümanların koruyucusu da olan Sultan, kâfir topraklarda hükmünü kabul ettirecekti. Bu söylem büyük ölçüde İbrahim Paşa ve danışmanı Gritti tarafından geliştirildi (Agoston 2011: 136). 
Milenyum kehanetleri Osmanlı dünyasında da vardı. Hicri takvime göre 1000 yılına yaklaşıldığı için, İslam coğrafyasının kontrol altına alınmasından sonra, sultanın kıyametten önce kurulacak son imparatorluğa hükmedeceğine inanılıyordu (Finlay 1998: 22). İbrahim Paşa hükmünü yansıttığ Sultan'ını Büyük İskender ile özdeşleştiriyor ve onun kurduğu imparatorluğun Sultan Süleyman'ın hükmü altında yeniden canlandıracağına kendisini ikna ediyordu (Agoston 2011: 137). Paşa, Venedik elçisiyle görüşmelerinden birinde efendisi ile okudukları eski bir kitapta İbrahim isimli bir kişinin çok yüksek bir siyasi mertebe kazanacağına ve bu kişinin efendisinin de Roma İmparatorluğu' nu ele geçireceğine dair bir rivayete rastladıklarını söyledi (Finlay 1998: 22). Böylece, adeta Avrupảnın basın ofisi olarak çalışan Venedik aracılığı kullanılarak Şarlken'e cevap veriliyordu. Esasen, askeri ve siyasi alanlarda çarpışan iki devlet değil, G. Agoston'un da araştırmasında ayrıntılarıyla tartıştığı üzere iki büyük stratejiydi (2011: 105-142) ve diğer devletler bu stratejiler içinde kendilerini konumlandırmaya çalışacaktı.

1525 yılında Şarlken’e esir düşen I. François’nın Osmanlı sarayına gönderdiği yardım talebine verilen olumlu yanıt bu çarpışmanın ilk canlı göstergesi olarak değerlendirilebilir (Charrière 1848-60, 2: 119-121; İnalcık 2001: 127-128). Rodos ve Belgrad'ın alınmasından sonra, Sultan Süleyman, Orta Avrupa’nın anahtarı olarak görülen Macaristan'a yöneldi. Macaristan topraklarında Osmanlı nüfuzunun derinleşmesi, aynı zamanda, Macar Kralı II. Lajos'un, Şarlken ve Avusturya Arşidükü olan kardeşi I. Ferdinand'ın kız kardeşi ile evli olması sebebiyle Habsburg İmparatorluğu'na vurulan bir darbe olacaktı. 1526 Mohaç Savaşı sırasında Lajos öldürülüp, Erdel Voyvodası Janos Szapolyai'nın Macar prensleri tarafından Macaristan Kralı seçilmesi, veraset yoluyla Macar Krallı̆̆g’ na sahip olduğunu iddia eden Şarlken ve Ferdinand tarafından kabul görmedi ve 1557 yılına dek sürecek ve bir Habsburg-Osmanlı mücadelesine dönüşecek Macaristan Meselesi'ni de başlatmış oldu (Fodor 1991: 271-345).

Ferdinand, Osmanlı ordularının şehri terk etmesinden kısa bir süre sonra Buda'ya girip 3 Kasım 1527'de Macar Kralı olarak taç giydi. Szapolyai ise hâkimiyetini yeniden kazanmak için Osmanlı yönetimine başvurdu ve elçisi Laski aracılığı ile Osmanlı Sultan’ından yardım istedi. Bu noktada, elçinin, İbrahim Paşa ile temas kurabilmek için Alvise Grtti'nin aracilığına başvurması ise dikkat çekicidir. Szapolyai'nın bir Osmanlı vasalı olmayı kabul etmesiyle neticelenen görüşmeleri müteakip Ağustos 1529'da, Szapolyai ile Sultan Süleyman Mohaç düzlüklerinde buluşup Buda kalesine ilerledi; 
Szapolyai, Macar Kralı olarak taç giydi ve Osmanlı orduları Habsburg İmparatorluğu’nun kıta Avrupa’sındaki merkezi Viyana’ya doğru yürüdü. Şarlken ve Ferdinand ile karşılaşmayan Osmanlı ordusu sefer zamanının da geçmesi sebebiyle 23 gün kuşattıkları şehirden çekildi.

Osmanlı müverrihleri Viyana Kuşatması'nı büyük bir zafer olarak nakledecekti. Büyük zafer, hemen Venedik'e duyuruldu. Divân tercümanı Yunus Bey, Sultan’ın fetihlerini anlatan bir fethnâmeyi Venedik'e götürdü. Sonraki yıl, Sultan Süleyman'ın şehzâdeleri için İbrahim Paşa’nın sarayında yapılan sünnet törenleri adeta bir güç gösterisine dönüştü. Osmanlı ile barış halinde olan Venedik Cumhuriyeti’nin elçileri de törenlerde hazır bulundular ve gözlemlerini devletlerine aktardılar. Bu noktada, Cumhuriyet, hem dost bir devlet olarak bilgilendiriliyor; hem de tüm istihbaratın toplanıp dağıtıldığı bir merkez olma özelliğinden dolayı, sarayın iletmek istediği mesajlar Venedik aracılığı ile tüm devletlere ulaştırılmış oluyordu.

Bu noktada, araştırmamızın temel konusu olan Osmanlı-Venedik ilişkilerinin doğasını net bir şekilde ortaya koyabilmek adına Venedik Cumhuriyeti'nin 16. yüzyıl başlarında izlediği siyasetin ve Habsburg ilerlemesi karşısındaki tutumunun tespit edilmesi yararlı olacaktır. Yukarıda bahsedildiği üzere, Habsburg İmparatorluğu'nun Avrupa kıtasında nüfuzunu arttırması Venedik için de oldukça dikkatli hareket planları yapılmasını zorunlu kılan bir siyasi programlamayı beraberinde getirmiştir. 15. yüzyılın sonlarında hemen hemen rakipsiz bir ticari güç olan Venedik İtalya yarımadasında bir yayılma politikası belirlemiş; Güneydoğu İtalya, Arnavutluk kıyılarıyla İyon adalarını da içeren Dalmaçya kıyılarını kontrol ederken, Milano Dükalı̆̆ı'na karşı harekete geçmişti. Venedik’in yayılmacı politikası İtalyan devletleri için bir tehdit oluşturuyordu. Bununla beraber İtalyan devletleri üzerinde hak iddia eden Fransa gibi diğer Avrupa devletlerine de yarımadaya girmek için zemin hazırlıyordus. Venedik yayılması Papalık, İspanya, Avusturya, Fransa ve Milano güçlerinin oluşturduğu Cambrai Ligi tarafından 1509 'da Agnadello'da durdurulmuştu. Öyle ki, Cumhuriyet, Venedik Lagünü dışındaki tüm topraklarını terk etmek durumunda kaldı. Aşamalı olarak kaybettiği geleneksel topraklarını geri alınsa da Venedik Lagünü’nün dahi işgal edilebileceği korkusu Venedik’te politika değişikliğine sebep oldu. Venedik Agnadello yenilgisinden sonra saldırgan tutumunu terk ederek savunma saflarını geliştirdi. Politikanın bir diğer önemli unsuru da silahlı mücadeleden uzak durarak, diplomasi ve ittifaklar yolu ile Venedik' in toprak bütünlüğ̈̈nü korumaktı. Cumhuriyet, devletlerin arasındaki rekabetleri gözetip kendi 
çıkarına göre saf değiştirerek, gelişkin diplomasisini kullanıp canlı ittifaklar kurarak topraklarını yabancı bir kuvvetin istilasından koruma yoluna gitti.

Venedik Cumhuriyeti'nin bu yeni savunma ve ittifaklar politikasının kurgu ve uygulanmasında araştırmamıza konu olan dönemde Venedik Doçu olarak görev yapan Andrea Gritti'nin katkısı çok büyüktü (Finlay 2000: 988-1031). Bu bağlamda Venedik en büyük ticari ortağı olan Osmanlı İmparatorluğu ile barış içinde olmaya titizlik gösteriyordu. 1503'teki Osman1-Venedik savaşının sonunda barışın yeniden tesis edilmesi için Osmanlı ülkesine elçi gönderen Cumhuriyet, aynı yıl yeni bir ahidnâme almayı başardı. Barış görüşmelerini yürüten elçinin yine Andrea Gritti olması da dikkat çekicidir. Sultan Süleyman'ın tahta çıkışı ile 1521 yılında Venedik ahidnâmesi yenilendi. Venedik ticari filoları ve Osmanlı Devleti hizmetine çalışan korsanlar arasında çıkan deniz çatışmaları dışında iki devlet silahlı bir mücadeleye girmedi. Bu, bilhassa Venedik' in kaçındığı bir durumdu.

1527 yllına gelindiğinde ise Venedik adeta bıçak sırtında yürümeye mecbur kaldı. 1525'te Fransa Kralı'nın Şarlken'e esir düşmesi ve 1527'de Habsburg güçlerinin Roma'ya girmesi Venedik'i Habsburg gücü karşısında iyice telaşlandırdı. Venedik, özellikle lagünü savunmak için tüm savunma mevziilerini güçlendirdi. Şarlken’i tetikleyecek ve Venedik'e yönlendirecek her türlü girişimi önlemeye çalışırken, diplomatik ilişkilerini güçlü tuttuğu ve ticari ortaklığını asla zedelemek istemediği Osmanlı İmparatorluğu'na yakınlığını korudu. Macaristan topraklarındaki gelişmeleri Venedik de dikkatle izliyordu. Macaristan'ın doğrudan Habsburg kontrolüne geçme ihtimali, Venedik'i endişelendiriyordu. Bu yüzden, İstanbul'da bulunan diplomatları aracılı̆̆ ile Habsburg İmparatoru'nun dünya hâkimiyetine göz diktiğine ve Macaristan'da Ferdinand'ın nüfuzunun artmasının Sultan'nın menfaatine aykırı olacağına Osmanlı yönetimini, bilhassa İbrahim Paşa’yı ikna etmeye çalışıordu (Fodor 1991: 295).

Venedik'in Alvise Gritti'ye olan yaklaşımı da yukarıda bahsedilen tutumu destekler niteliktedir. İbrahim Paşånın danışmanı olarak dikkat çeken Venedikli, Ferdinand'ın Buda'ya girmesini takiben Szapolyai'nın Osmanlı ülkesine gönderdiği elçisi Laski için yaptığı arabuluculuk sayesinde Szapolyai'nın da danışmanı oldu (Szakaly 1995: 46, Otman 2012: 137). Bir yandan da Osmanlı'nın sefer hazırlıklarına destek veriyor, İbrahim Paşa ile sefere katılacağını Venedik'e bildiriyordu. Habsburg İmparatorluğu'nu doğrudan ilgilendiren bu meselede Doç’un oğlunun bu kadar aktif bir görev alması Ve- 
nedik’i şüpheli bir durumda bırakabilirdi. Bu sebeple Doç Gritti, Alvise’ye, Szapolyai'ya gönderdiği mektupları, ismini açıkça yazmak yerine, "sizin sadık hizmetkârınız” diye imzalamasını söyledi'. Ancak 5 A ğustos 1529'da Fransa Kralı Cambrai Antlaşmasını imzalayıp, İtalya üzerindeki tüm kazanımlarından Habsburg İmparatoru lehine vazgeçince Venedik, Osmanlı Sarayı'na daha fazla yakınlaşmaya mecbur kaldı. Oğluna hitaben yazdığı mektuplarda, Doç Gritti, Venedik'in durumu hakkında bilgi veriyor, İbrahim Paşa'nın derhal durumdan haberdar edilmesini istiyor ve gerektiğinde liman ve deniz güçleri ile Osmanlı ordusunu destekleyeceğini söylüyordu ${ }^{7}$. İbrahim Paşa’nın, Gritti'nin de etkisiyle, Cumhuriyet'in talebine kayıtsız kalmayacağı umuluyordu.

1529 yılının güzünde Viyana’nın düşmemesi, kuşatmaya bir anlamda gizliden destek vermiş olan Venedik açısından tam bir hayal kırıklığı oldu. Aralık 1529'da Venedik, Habsburg İmparatoru ile barış imzalamaya mecbur kaldı. Yaklaşık 2 ay sonra Şarlken Bologna’da Kutsal Roma İmparatoru olarak taç giydi. Cumhuriyet bu noktadan sonra çok daha ihtiyatlı davranmak zorunda kalacaktı.

\section{İmparatorların Rekabeti: Alaman Seferi (1532)}

Şarlken'in Kutsal Roma İmparatoru olarak taç giymesi ve İtalyan yarımadasında hâkimiyetini güçlendirmesi Osmanlı-Habsburg rekabetinde yeni bir sayfa açtı. Evrensel imparatorluk iddiasına sahip Sultan Süleyman, Şarlken’in imparatorluğunu tanımıyor, kendisini İspanya Kralı olarak adlandırıyordu. Viyana kuşatmasının ardından Ferdinand güçlerinin Buda şehrini tekrar kuşatması Sultan'ı Ferdinand'a karşı yeni bir askeri harekâta sevk etti (Celâlzâde 2011: 171). Alvise Gritti yeniden Macaristan’a gönderildi. Gritti ordu için hem mühimmat ve yiyecek stoklarını hazırlayacak hem de otoritesini yeniden tesis etmesi için Ferdinand ve Macar Beyleri'ne karşı savaşan Szapolyai'ya Türk Sözcüsü̈ olarak yardım edecekti (Barta 2008: 256, Otman 2012: 140). Venedikli görevinde başarılı oldu ve Szapolyai tarafindan Macaristan Valisi olarak atandı. Macaristan'ın ardından, Ağustos 1532'de Osmanlı ordusu Alman topraklarına hareket etti. Yaklaşık 3 hafta içinde ordu, Güns kalesini ele geçirdi. Sultan Süleyman o sırada Lintz şehrinde bulunan Şarlken’i savaş meydanına davet etti (Gökbilgin 2001: 22). Ordunun bir kolu da Estergon kalesini kuşattı. Böylece Habsburg güçleri iki kanada bölünerek zayıflatılacak ve Viyana’ya girilecekti (Kumrular 2007: 59). Aynı anda Osmanlı donanması da Preveze Limanı'na geldi. Böylece Akdeniz'den 
gelecek bir saldırı için de önlem alınmış oldu.

$\mathrm{Bu}$ askeri harekât, İbrahim Paşa tarafından ideolojik bir mukabele ile de güçlendirildi. Paşa, sefer sırasında sergilenmek üzere büyük bir regalia hazırlattı. Sultan Süleyman için mücevher nakışlı bir taht ve asa yapıldı. Dört tacın üst üste geçirilmesiyle oluşturulan, elmas ve pırlantalarla bezeli bir de altın miğfer tasarlandı. Bu miğfer şaşırtıcı derecede Papa’nın törenler sırasında giydiği tiara isimli başlı̆̆a benziyordu (Kurz 1969: 249-258, Necipoğlu 1989: 401-408). Venedik'te hazırlanan bu regalia için çalışan ekibin çoğunluğunun Alvise Gritti'nin himayesindeki insanlardan oluşması da ilginçtir (Necipoğlu 1989: 410-415). Burada Paşa’nın amacı, tek bir evrensel imparatorluk olduğunu ve onun gerçek imparatorunun da Osmanlı Sultanı olduğunu, Hristiyan dünyasına ait sembolleri kullanarak Papa’ya ve Şarlken ile beraber tüm taçlı başlara kanıtlamaktı (Necipoğlu 1989: 415-416). Ayrıca, Ferdinand'ın Sultan ile görüşmek üzere Niş şehrine gelmiş olan elçilerinin Osmanlı ordularının şehirden geçişlerine tanıklık etmesi de temin edildi (Celalzâde 2016: 29-34, Kurz 1969: 256). Böylece yine Şarlken'in taç giyme töreninde yapılan geçide cevap verilmiş oluyordu (Agoston 2011: 139). Orta Avrupa’nın merkezine yönelen bir seferde bu denli güçlü bir ideolojik sunum hazırlanması, İbrahim Paşånın Hristiyan dünyasını ve onun algı biçimlerini ne denli iyi tanıdığını göstermektedir (Agoston 2011: 139-140). Paşaya bu noktada, Avrupa siyasi ve ideolojik kavramlarına oldukça hâkim olan Gritti'nin de kaynaklık etmiş olması kuvvetle muhtemeldir (İnalcık 2009: 155).

Titizlikle kurgulanan güç gösterisi çok başarılı olsa da 1532 Alaman Seferi'nin Osmanlı İmparatorluğu açısından büyük bir askeri başarı olarak değerlendirilmesi güçtür. Gerek, hâlihazırda Protestan Alman Prensleri ile de mücadele eden Şarlken'in kardeşini Sultan'la barış müzakerelerine zorlaması (Agoston 2011: 138); gerekse savaşın Osmanlı İmparatorluğu için mali bir yüke dönüşmesi seferin sonlandırılmasına sebep oldu. Macaristan Meselesi ise, seferden sonra diplomatik manevralar ile çözüme kavuşturulmaya çalışıldı ${ }^{9}$. Ancak, Alaman Seferi de Viyana Kuşatması gibi, Osmanlı dünyasında büyük bir zafer olarak değerlendirildi. İbrahim Paşa, Ferdinand'a yazdığ mektupta her yerde Şarlken'i aradıklarını ama bulamadıklarını belirtiyordu (Zinkeisen 2011, 2: 523). Osmanlı müverrihleri de durumu benzer bir biçimde aktaracaklardı. İstanbul'da beş gün beş gece süren eğlenceler yapıldı ve fethnâmeler hazırlandı (Celâlzâde 2011: 189). 
1532 Seferi, kara savaşlarının yanında, Osmanlı-Habsburg rekabetinin Akdeniz ve Adriyatik'te yapılacak deniz savaşlarına taşınmasına zemin hazırlaması bakımından da önemlidir. Bunun ilk örneği ise Osmanlı ordusunun geri çekilmesi sırasında Habsburg donanmasına komuta eden ve yaz boyunca Sicilya'da bekleyen Andrea Doria’nın Mora Yarımadası'nın önemli kilit noktalarından biri olan Koron'u ele geçirmesi olmuştur (Zinkeisen 2011, 2: 525). 1 yıl sonra Koron Osmanlı güçleri tarafından geri alınsa da bu kayıp İbrahim Paşąyı deniz stratejisi belirleme konusunda uyarıcı nitelikte olmuştur (İnalcık 2009: 156).

Öte yandan, 1532 Seferi, Osmanlı-Venedik ilişkileri açısından önemli değişimlere sebebiyet verdi. Venedik, sefer sırasında yine tarafsızlığını korumayı sürdürdü. Her ne kadar Şarlken'le barış imzalamış olsa da Papalık'ın ve Şarlken'in tüm zorlamalarına karşın sefer sırasında karadan ve denizden destek göndermeyi reddetti. Olası bir saldırıya karşı savunma saflarını güçlendiren Venedik, Doğu Akdeniz’e 60 silahlı kadırga yollasa da Korfu Adası'nda düşman hareketini gözlemekle yetindi. Donanma kaptan $1^{10}$ Vicenzo Capello'ya da tamamen tarafsız kalması ve asla yabancı donanmalara karışmaması emredildi (Paruta 1703, 1/ 1.7: 327-328). Venedik Osmanlı İmparatorluğu ile arasında olan barışı bozmaya niyetli değildi. Ancak, bu durum Osmanlı yönetimi tarafından olumlu karşılanmadı. Venedik' in Habsburg İmparatoru ile barışşartlarını kabul etmiş olması, Cumhuriyet' in Osmanlı Sultanı’na duyduğu sadakatin sorgulanmasının önünü açtı. Ayrıca, Koron'a yapılan saldırıda da Venedikli güçlerin destek verdiği düşünüldü. Celâlzâde, Koron'un bizzat Venedikliler tarafından alındığını nakleder (2011: 193-194). Habsburg güçlerinin Venedik'in desteğini almadan Koron yakınlarında serbestçe seyretmesinin mümkün olamayacağ 1 da bilinmektedir (Gürkan 2011: 16-17). Bu sebeple 1532 Aralı̆ğında Tercüman Yunus Bey’in bir kez daha yapılan fetihleri bildirmek amacıyla Venedik'e gönderilmesinin altında, Venedik yönetiminin izlediği politika hakkında uyarılması gayesinin de olması muhtemeldir (Aydın 2007: 49). Bu noktadan sonra İbrahim Paşa da Venedik'i yürürlükte olan ahidnâme uyarınca davranmak konusunda zorlayacaktır. Öte yandan Osmanlı güçlerinin Habsburg güçlerine karşı kesin bir başarısının olmayışı, Venedik'i yeni bir durum değerlendirmesi yapmaya yöneltecek; Cumhuriyet, kendi varlık ve kazanımlarını korumak adına korumaya çalıştığı siyasi dengeyi Habsburg tarafına doğru kaydırmaya başlayacaktır. 


\section{İbrahim Paşa ve Venedik: Algı ve Yaklaşımlar (1524-1536)}

Yukarıda belirtildiği gibi, 1532 yılına dek Osmanlı’nın Habsburg İmparatorluğu karşısında net bir başarı kazanamaması, Venedik Cumhuriyeti'nin de Osmanlı Devleti'ne ve onun en kudretli devlet adamı İbrahim Paşa'ya yönelik yaklaşımını değiştirmiştir. Venedik elçilerinin Senatơ ya sundukları relazioneler incelendiğinde Paşa ile ilgili algının nasıl değiştiği tespit edilebilir. Elçi yardımcısı ve sözcü olarak Osmanlı başkentinde bulunan ve Kasım 1524 'te ülkesine dönerek gözlemlerini Senato ile paylaşan Pietro Zen, İbrahim Paşåy çok bilge ve kibar biri olarak nakletmiştir (Alberi 1840-1855, 3/3: 94). Benzer bir biçimde, balyos Pietro Bragadin de 1526 'da "Sultan'ın kalbi ve nefesi” olarak tanımladığı İbrahim Paşảnın, Osmanlı hukukunu bildiği kadar çağdaşı olan hükümdarların durumunu merakla takip eden, Büyük İskender ve Hannibal gibi antik hükümdarların hayatlarına dair kitaplarla tarihteki büyük savaşları nakleden hikâyeleri okumaya oldukça meraklı çok akıllı, bilge ve adaletli bir kişi olarak tariflemiştir. İbrahim Paşa’nın lüks ve gösterişe düşkünlüğünün de altını çizen balyos, onun Sultan'dan bile daha gösterişli giyindiğini ve çok değerli yüzükler taktığını belirtmiştir. Bragadin'in altını çizdiği bir diğer husus da, Paşa'nın Venedik ile dostluk içinde olduğudur (Alberi 1840-1855, 3/3: 103). Mohaç Zaferi'ni kutlamak üzere İstanbul'a gönderilen Marco Minio'da Paşa'yı istediği her şey yapılan çok güçlü bir adam olarak yansıtmıştır. Minio, "adeta Sultan" diyerek güç ve etkisini anlattığı Paşa’nın babası ile de görüşme firsatı bulmuş ve Rodos ile Macaristan'ın ardından yapılacak büyük seferin İtalya üzerine olabileceği bilgisini kendisinden edinmiştir (Alberi 1840-1855, 3/3: 113-118). Elçilerin İbrahim Paşa'yı anlatırken kullandıkları muhteşem sıfatı dikkat çekici$\operatorname{dir}^{11}$. Alvise Gritti ve Andrea Gritti'nin yukarıda bahsedilen mektuplarında da bu sıfat kullanılmıştır. Paşa'nın gerek yönetici, gerek kişilik vasıfları ile Venedik temsilcileri tarafından son derece olumlu algılandığı ve yansıtıldığı açıktır.

Elçi Sekreteri Daniello de Ludovisi'nin Haziran 1534'te Senato'da okuduğu raporda ise bambaşka bir İbrahim Paşa tarifi karşımıza çıkmaktadır. Sadrazam bulunduğu mevkie gelebilmek için türlü kurnazlıklar yapan, Sultan’a sadece kendisinin yakın olabilmesi için liyakati olan ve Sultan'a gerek askeri gerek idari konularda nasihatler verebilecek isimleri devre dışı bırakan biri olarak yansıtılır. Aynı zamanda Sultan'ın ordusu ve hükmü altında olan toprakların yapısı ile ilgili teferruatlı bilgiye sahip olmadığı ve tüm işleri 
İbrahim Paşảnın tasarrufuna bırakarak da ihmalkâr davrandığı söylenir ${ }^{12}$. Ludovisi, Paşa'nın Venedik'le dostluğu devam ettirme niyetinde olduğunun, bu dostluk bozulursa kendisinin de büyük zarar göreceğini bildiğinin de altını çizmiştir. Sekreter'in raporunda oldukça dikkat çekici bir nokta da İspanyol ve Alman askeri sistemi ile Osmanlı ordusunu karşılaştırması ve Alman ordularının Osmanlı ordusu tarafından mağlup edilemeyeceğini belirtmesidir. Şarlken'le Sultan Süleyman arasında bir kara savaşının çıkmasını bu sebeple çok olası görmediğini, daha önceki çarpışmalarda da Sultan'ın başarılı olmadığını belirtmiştir. Ancak Şarlken'in bir donanma tertip etmesiyle denizde olacak bir karşılaşmanın Osmanlı Sultanı'na daha büyük zarar vereceğini de not düşmüştür ${ }^{13}$. Osmanlıların deniz ticaretinde faal olmadıkları için, donanma olarak da çok gelişmediklerini ${ }^{14}$; denizlerle ilgili her tedbir için Barbaros Hayreddin Paşaya güvendiklerini ancak Paşa’nın gerekli taktiksel plan ve hazırlıkları yapacak kadar başarılı olmadığını da belirtmiştir. Ludovisi, ilginç bir şekilde, imparatorun ölümü durumunda Habsburg hükümdarlığına ait güçlerin bölünebileceğini ve Osmanlı Sultanı’nın bu durumda belki de Venedik'le dost kalmayacağını da belirtmiştir. Osmanlı devlet ve ordusunun durumu hakkında imparatoru haberdar edip etmeme hususunu ise Senato'nun değerlendirmesine bırakmıştır (Alberi 1840-1855, 3/1: 1-32) Ludovisi'nin raporu sadece İbrahim Paşa’ya dair algının değişmesi yönünde değil, aynı zamanda 1532 'den sonra Osmanl1-Habsburg mücadelesinde Osmanlı'nın nasıl değerlendirildiği konusunda da aydınlatıcı bilgiler sunmaktadır. Kara savaşından deniz savaşlarına genişleyecek olan mücadelenin hazırlık aşamaları da raporda belirtilmiştir. Ludovisi'nin raporunda tafsilatlı olarak Osmanlı ordu ve donanmasının durumunu anlatması ve onların kolaylıkla mağlup edilebileceğini yansıtması da bir anlamda Venedik'e Habsburg tarafına yakınlaşmanın daha yararlı olacağı yönünde mesaj vermek amacını taşımaktadır.

1534 sonrası gelişmeler Ludovisi'nin raporunda belirttiği istikamet doğrultusunda ilerledi. Osmanlı hesabına çalışan Cezayir Beylerbeyi Barbaros Hayreddin Paşa, Koron'u yeniden kontrol ettikten sonra İstanbul'a geldi ve Sultan tarafindan kaptan-1 derya olarak atandı. Barbaros'un görevi Osmanlı donanmasını yeni kadırgalar ile güçlendirerek Andrea Doria'nın donanmasına mukabele edebilecek bir deniz filosu oluşturmaktı. Birkaç ay sonra Andrea Doria’nın da destek verdiği Habsburg donanması Tunus’a girdi ve stratejik olarak önemli olan La Goletta bölgesini hâkimiyet altına aldı. Yakın zamanda, imparatorların savaşına amirallerin mücadelesi de eklenecek, 
Osmanlı-Habsburg rekabetinin ikinci bir ayağı da Akdeniz'de bir güç mücadelesine dönüşecekti.

Öte yandan, Fransa-Osmanlı ittifakı yeni bir boyut kazanıyordu. Fransız elçisi, Jean de la Foret, Irakeyn Seferi dolayısı ile İran'da bulunan Sultan ve İbrahim Paşa ile buluşarak, Osmanlı Sultanı’nı İtalya üzerine yapılacak ortak bir sefer için ikna etmek amacıyla müzakerelere başladı. Fransa Kralı, Osmanlı askerleri Güney İtalya'ya girerken, eş zamanlı olarak Lombardiya’ya girmeyi taahhüt ediyor ve Osmanlı donanmasını deniz gücü ile destekleyeceğini söylüyordu (Zinkeisen 2011, 2: 541-543). Elçi görüşmelerinde başarı sağladı. İtalya üzerine yapılacak ortak hareketin kabulünün yanı sıra Fransa Krallığı dost bir ülke olarak Osmanlı toprakları içinde serbest ticaret yapma ve daimi elçi bulundurma hakkı kazandı. Sultan Süleyman ve I. François tarafından onaylanmamış olsa da (Isom-Verhaaren 2011: 32), Ocak 1536 'da İbrahim Paşa tarafindan onaylanan bu antlaşma ile Fransa, Osmanlı İmparatorluğu’nun en yakın müttefiki haline gelecekti. Üzerinde anlaşılan ortak hareket planı ise ancak 1537 yazında gerçekleştirilebilecekti. Ne var ki, Fransa vaat ettiği gibi Kuzey İtalya topraklarına girmeyecek, Osmanlı güçleri İtalyảnın Apulia bölgesini talan ettikten sonra, Venedik’e bağlı Korfu Adası'na yönelecekti.

Bu dönemde Venedik Cumhuriyeti'nin izlediği siyaset ise Osmanlı yönetiminde şüphe uyandırmaya başladı. 1529 ve 1532 Seferleri'nde ahidnâmeye uygun olarak Osmanli'ya gereken desteği vermemekle ve Koron'un kaybında kendisine bağlı tebaanın Andrea Doria güçleri ile ortak hareket etmelerine göz yummakla yaftalanan Cumhuriyet şimdi de Habsburg İmparatoru'na yardım etmekle suçlanıyordu. Fransız diplomatları bilhassa İbrahim Paşa'yı, Venedik'in Habsburg İmparatoru'nu Osmanlı ülkesine saldırmak konusunda kışkırttıklarına, hatta Andrea Doria’nın 1535'te Tunus'u ele geçirmek için yaptığı savaş hazırlıklarını gizliden desteklediklerine inandırmayı başarmıştı (Zinkeisen 2011, 2: 547). Bununla beraber, Osmanlı ve Venedik'e ait ticaret gemileri Akdeniz'de birbirlerinin saldırılarına uğruyordu. Bu noktada, sadarete geldiğinden bu zamana dek Venedik'e oldukça ılımlı yaklaşan İbrahim Paşa’da Cumhuriyet'i daha ciddi uyarma ve ahidnâme koşullarını hatırlatma ihtiyacı duydu.

1535 Martında Doç Gritti’ye yazdığı mektupta Sadrazam Irakeyn seferi hakkında bilgi verdikten sonra, Osmanlı'nın sonraki seferinin Akdeniz'e olacağını ve iki devlet arasındaki kadim dostluk uyarınca Barbaros Hayred- 
din Paşa ve diğer Osmanlı kuvvetleri ile Venedik'in, düşman kuvvetlerine karşı birlikte hareket etmesi gerektiğini bildirerek, düşman hareketi konusunda Venedik'in Osmanlı'yı haberdar etmesini de hatırlattı ${ }^{15} .2$ ay sonra yazdığı bir diğer mektupta ise Paşa, İspanya Kralının Almanya topraklarına geldiği bilgisine kendilerine Venedik tarafından değil başkaları tarafından iletildiği için fazla ehemmiyet göstermediklerini bildirirken Doç’tan bu bilginin doğruluğunun teyidi ile birlikte Kral'ın manevraları hakkında ayrıntılı istihbarat istedi. Paşa Doç’u ve tüm Venedik yöneticilerini Osmanlı Devleti ile aralarında olan barış uyarınca her türlü haberin Divân'a en önce Venedik tarafından gönderilmesi hususunda uyard ${ }^{16}$. Kasım 1535 'te yazılan bir başka mektupta İbrahim Paşa, Venedik ve Fransa’ya yardım etmek için harekete geçen Barbaros Hayreddin Paşa komutasındaki kadırgalara yapılan Habsburg saldırısında Venedik’in kendilerini sadece bilgilendirmekle yetindiğini; Osmanlı kuvvetlerine yardım etmediklerini belirtti; bir dost ve müttefik olarak Venedik'in daha fazlasını yaparak Osmanlı güçlerine destek vermesi gerektiğini vurguladı. Osmanlı'nın Kuzey Afrika'da bulunması, Paşa'ya göre Venedik ve ona bağlı toprakların güvenliğini teminat altına almaktayd ${ }^{17}$. İbrahim Paşa'nın mektupları var olan ahidnâme gereğince Osmanlı'nın Venedik'ten beklentilerini açıkça ortaya koymaktadır. Öte yandan Cumhuriyet' in izlediği tarafsızlık karşısında Venedik' in dostluğu hakkında şüphelerin güçlendiği de yansıtılmaktadır. Sadrazamın doğrudan Doç’a yaptığı uyarılarda Osmanlı-Fransız ittifakından bahsedilmekte; bir anlamda da Venedik'in bu ittifaka destek vermesi gerektiği hatırlatılmaktadır.

Venedik, sınır çatışmalarını ve denizlerde yaşanan karşılıklı saldırıları diplomatik girişimleri ile çözümlemeye çalışmışsa da Osmanlı-Habsburg mücadelesinde etkin olarak Osmanlı güçlerine destek vermekten kaçınmıştır. Osmanlı-Fransız ittifakında da tarafsız kalmıştır. Habsburg İmparatoru ile imzalanan barışa karşın Venedik Senatosu, özellikle Osmanlıların Akdeniz’de hareketliliğinin arttığı dönemlerde, Habsburg güçlerinin yardım çağrısını da reddetmiştir. Osmanlı Sultanı'na karşı, Habsburg İmparatoru’nu desteklemeyi Cumhuriyet' in çıkarları adına daha yararlı gören Senato üyelerinin muhalefetine karşın Doç Gritti, müttefikinin tepkisini çekecek herhangi bir ortaklığa girmekten özellikle kaçınmış; Venedik'e ait Korfu Adası'na yönelecek olan 1537 Seferi öncesinde Andrea Doria'dan gelen savunma yardımı teklifini dahi reddetmiştir (Zinkeisen 2011, 2: 548). Ne var ki Venedik'in bu tarafsızlığı, Osmanlı dünyasında ikiyüzlü bir siyaset olarak değerlendirilmiş; Venedik düşmanla ittifak yapmakla suçlanmıştır. Bu 
durum, Sadrazam İbrahim Paşa’nın idam edilmesinden 1 yıl sonra gerçekleştirilecek Korfu Kuşatması'nın da meşruiyet zeminini oluşturacaktır (Âlî 2009: 306a, Celâlzâde 2011: 221).

\section{Sonuç}

Yukarıda tartışıldığı üzere, İbrahim Paşa’nın Osmanlı sadrazamlığı görevini yürüttügü 13 yıl boyunca Osmanlı Devleti ve Venedik Cumhuriyeti arasındaki barış bozulmamış ve iki devlet arasındaki siyasi ve ticari ilişkiler geliştirilmiştir. Venedik diplomatları ve tüccarları korunmaya devam etmiş ve kendilerine ayrıcalıklar sağlanmıştır. Venedik, bu süreçte Osmanlı nezdinde bilgi akışını sağlayan bir istihbarat kolu olarak değerlendirilmiş, Batı'daki siyasi gelişmeler hakkında Venedik aracıllı̆ı ile malumat elde edinilirken, Osmanlı seferleri ve devlet politikası ile ilgili bilgiler de yine Venedik aracıllı̆ı ile batı dünyasına nakledilmiştir. Ahidnâme koşulları uyarınca, Osmanlı ülkesinde bulunan Venedik diplomatlarının yanı sıra, Osmanlı hükumetinin de gerektiğinde Cumhuriyet'e elçi yollaması bu durumun en güzel göstergesidir. Bununla beraber, Venedik, dost bir devlet olarak, Osmanl1-Habsburg rekabeti çerçevesinde, Osmanlı tarafında hareket etmeye davet edilmiş; iki devlet arasında savaşa dönüşebilecek her türlü girişimden kaçınılmıştır.

Saptamalarımıza göre, İbrahim Paşa, Osmanl1-Venedik ilişkilerini bu dönemde dengede tutan en önemli isimdir. 1536'da İbrahim Paşa’nın idam edilmesinin hemen ardından, yine bir Habsburg-Osmanlı karşılaşması olarak planlanan 1537 seferi sırasında Osmanlı donanmasının Venedik'e bağlı Korfu Adası'na yönelmesi ve Venedik'le süren 34 yıllık barışın bozulması bu iddiayı kanıtlamaktadır. Korfu Kuşatması, Osmanlı-Venedik ilişkileri açısından bir dönüm noktası olarak değerlendirilmelidir. Osmanlı ile yürüttügü siyasi, diplomatik ve ticari ilişkilerini zedelemekten kaçınan Venedik, bu savaştan sonra İmparator ve Papalık saflarında yer almış; her ne kadar 1540 yılında Osmanlı Devleti ile yeni bir barış imzalamış olsa da, Sultan nezdindeki ayrıcalıklı müttefik konumunu Fransa lehine kaybetmiştir.

Mevcut çalışmalar, İbrahim Paşa’nın Venedik’e karşı izlediği siyaseti, Paşảnın kökeni ve Venedik'e beslediği kişisel sempati ile ilişkilendirmektedir. Ancak, çalışmamız açıkça orta koymaktadır ki, Paşa, ustalıkla kurguladığı ve yürüttüğü evrensel imparatorluk siyasetinde Habsburg gücüne karşı yürütülen siyasi, askeri ve ideolojik mücadelede Venedik’i adeta bir ara eleman 
olarak kullanmıştır. Yarımadanın en güçlü şehir devleti olan Venedik, İtalya’da büyüyen Habsburg tehlikesine direnebilecek en büyük güç olduğundan Osmanlı yönetimi, bilhassa İbrahim Paşa, tarafından desteklenmiş ve Osmanl’nın Avrupa fetihlerinde basamak taşı olarak kullanılan Macaristan ve Arnavutluk sınırları ile Akdenizde, Osmanlı Devleti'nin elini zayıllatacak yeni kargaşaların oluşmasının önüne geçilmeye çalışılmıştır. Bu noktada, İbrahim Paşånın Venedik'e olan yaklaşımını ve 16. Yüzyılın ilk yarısındaki Osman11-Venedik ilişkilerini belirleyen ana unsurun uluslararası siyasi dengeler olduğu açıktır. Paşa’nın sadrazamlık döneminin son yıllarında yeni bir biçim kazanan Osmanlı-Fransız ittifakını da yine bu çerçevede değerlendirmek doğru olacaktır. Gerek Venedik, gerek Fransa, Şarlken'in Kutsal Roma İmparatoru sıfatıyla tüm Avrupa'yı tek bir siyasi ve ideolojik şemsiye altında toplamasını önlemek için siyasi, askeri ve ekonomik anlamda desteklenmiştir.

Ancak, çalışmamızda işaret ettiğimiz üzere, Venedik’in, Osmanlı’nın özellikle Macaristan ve Avusturyàya gerçekleştirdiği seferlere doğrudan destek vermemesi, Habsburg İmparatoru ile barış imzalaması, Akdeniz'de savaşa hazır silahlı donanma bulundurması, Osmanlı kadırgalarına yapılan saldırılar ve İmparator'un hareketleri ile ilgili bilgileri payitahta iletmekte çekimser kalması iki devlet arasındaki ilişkileri zedelemiştir. Venedik'in kendi toprak bütünlügünü ve bağımsızlığını korumak için izlemek zorunda kaldığı tarafsızlık politikası bu durumun temel nedeni olarak ortaya çıkmaktadır. Bu noktada Paşa’nın Cumhuriyet'e yaklaşımı da sertleşmiştir. Venedik elçilerinin raporlarında İbrahim Paşàya dair mevcut algının değişmesi yine bu durumun bir sonucu olarak değerlendirilmelidir.

İbrahim Paşa’nın sadaret dönemi ile ilgili vurgulanması gereken bir diğer husus da, kendisi tarafından ustalıkla kurgulanan Osmanlı Devlet' inin batı siyasetinde, Hristiyan dünyaya ait söylem ve kavramların en güçlü şekilde ilk defa kullanıldığıdır. Görüldüğü gibi bu dönemde Osmanlı Devleti, Doğu'da büyüyen ve Hristiyan dünyasını tehdit eden bir güç olmaktan çok, batı siyasetinin içinde, ona kendi diliyle seslenen en etkin ve belirleyici dünya gücü konumuna gelmiştir. Paşa’nın siyasi yaklaşımlarının düşünsel alt yapısını oluşturan en önemli unsurların Batı kültüründen geldiği aşikârdır. Mevcut çalısmalarda belirtildiği üzere, Avrupa dünyasına ait ilgisi kendisine Frenk lakabı takılmasına yol açacak kadar göz önünde olmuştur. Bu noktada, gerek temas halinde bulunduğu Venedikli diplomat ve tüccarların, gerekse dostu ve danışmanı Alvise Gritti'nin, Paşa'nın söylemini oluşturma- 
sında oldukça önemli rol oynadıkları da iddia edilebilir. Gritti'nin aktif siyasette üstlendiği görevler, Paşa üzerindeki etkisini kanıtlar niteliktedir. Paşa, Venedikli'yi hem bir siyasi danışman, hem de kendi siyasetini uygulayacak bir eleman olarak ustalıkla kullanmıştır.

\section{Açıklamalar}

1 Araşıırmacı alter ego kavramını "diğer benlik" anlamıyla kullanmıştır. Burada kastedilen Sultan Süleyman'ın İbrahim Paşàyı kendisinin birebir yansıması olarak değerlendirdiğidir.

2 Venedik elçi ve diplomatik görevlilerinin görev süreleri sonunda ülkelerine dönüşlerini takiben Senato huzurunda okudukları rapora verilen ad.

3 Beyoğlu üstüne yapılan çalışmalarda ismin bu bölgede yaşamış ünlü bir prensten ileri geldiği saptanmıştır. Bu ünlü prensin metinde bahsedilen Alvise Gritti olduğu savı Osmanlı belgelerinde de Gritti’nin Beyoğlu olarak anılması ve bahsedilen semtte bir sarayda yaşaması sebebiyle daha güvenilir bulunmaktadır (Otman 2012: 127).

4 Alvise Gritti'nin Venedik Senatosu’na yazdı̆̆ 4 Şubat 1526 tarihli mektup. VDA, Dispacci Degli Ambasciatori al Senato, f. 1A.

5 Literatürde İtalya Savaşları adıyla bilinen 1494-1559 yılları arasında yapılan savaşlar ilk olarak Venedik’e karşı Milano Dükalığı’nın Fransa Krallığı'nı yardıma çağırması ile başlamıştır. Dönemin Fransa Kralı 8. Şarl İtalya işgaline yönelince Venedik, Papalık, Napoli Krallığı, İspanya ve Avusturya güçleri birleşerek Fransız ordusunu saf dışı bırakmıştır.

6 Andrea Gritti'nin Alvise’ye yazdığ 18 Mart 1528 tarihli mektup. VDA, Consiglio dei Dieci, Parti Secrete, Reg. 2, 52v-53r.

7 Venedik Devlet Arşivi'nde bulunan Ducali ed Atti Diplomatici koleksiyonunun 22. Dosyasında Doç tarafından oğluna yazılan 1529 tarihli çok sayıda kısa mektup bulunmaktadır. Bu mektupların pek çoğunda Venedik'in Osmanlı ile arasındaki barışı korumakta kararlı olduğu ve İbrahim Paşảnın Cumhuriyet'in içinde bulunduğu zorlu durumdan haberdar edilmesi istenmektedir.

$8 \quad$ Orator Turchi

9 Macaristan Meselesi için Ferdinand ve Szapolyai'nın elçileri ile yapılan görüşmelerde, İbrahim Paşa yine Alvise Gritti'yi yetkilendirdi. Ancak, Gritti bu görüşmelerde ikiyüzlü bir tutum sergiledi. Ayrıca, Macar Prensleri de kendisinin Macaristan Krallığı'nı ele geçireceğinden kuşkulanıyordu. 1534'te Macaristan'a yaptığı son yolculukta, Gritti muhaliflerinin şiddetli tepkisi ile karşılaştı. Boğdan Voyvodası Petru Rareş'in komutanı Hurul tarafından yakalandı ve öldürüldü (Szakaly 1995: 19-34, 78-79). Macaristan Meselesi ancak Zapolya’nın ölümünü müteakip 1541 Budin Beylerbeylği'nin kurulması ve 1547 'de Ferdinand'ın Macaristan üzerindeki tüm haklarından vazgeçip Osmanlı Devleti'ne yıllık vergi ödemeyi kabulüyle neticelendi (Uzunçarşılı 2006, 2: 337-340). 
10 Capitano Generale. Burada adı geçen Capello, Venedik donanmasının tamamina komuta etmemektedir. O dönmede savunma amaçlı hazır bulunan donanmanın komutasından sorumludur.

11 Muhteşem sıfatı sadece İbrahim Paşa’nın özelinde kullanılmamıştır. Daha sonraki döneme ait bazı raporlarda da sadrazamlar "muhteşem paşa” diye adlandırılmıştır.

12 Ludovisi'nin raporunda bahsedilen dönemde mirahor olan daha sonra ise sadrazamlığa yükselecek Rüstem Paşådan da bahsedilmesi ilgi çekicidir. Sekreter, Rüstem Paşa’nın Sultan'a yakınlaşması nedeniyle İbrahim Paşa'nın dikkatini çektiği ve onu Sultan'dan uzaklaştırmak adına Anadolu’ya göndermeye karar verdiğini belirtmiştir.

13 Ludovisi burada Koron'un alınmasının güzel bir gösterge olduğunu da belirtir.

14 Rapordaki bir ilginç ayrıntı da, Ludovisi'nin Fransızların, Sultan Süleyman'la birlikte imparatorun gücünün daha fazla büyümemesi için ortak hareket etmek istediklerini ve dostluk görüşmelerini başlattıklarını bildirmesidir. Kendisi bu görüşmelerden büyük bir plan çıkacağını tahmin etmediğini de not etmiştir.

15 İbrahim Paşa’nın Andrea Gritti'ye yazdığı mektup (Evasıt-1 Ramazan 941/ 4 Mart 1535) VDA, Documenti Turchi, Sala Regina Margherita, Turchia Firmani, s. 4XXXVI, no:6. M.Tayyip Gökbilgin tarafından Osmanlıca olarak yayımlanmıştır (Gökbilgin 1968-1971: 54-56).

16 İbrahim Paşa’nın Andrea Gritti’ye yazdığı mektup (Zilkade 941/ Mayıs 1535) VDA, Documenti Turchi, Busta 7, s. 8, fasc. 29, Pezzi 4. M. Tayyip Gökbilgin tarafından Osmanlıca olarak yayımlanmıştır (Gökbilgin 1964: 156).

17 İbrahim Paşa’nın Andrea Gritti'ye yazdığı mektup. (Rebiülevvel 942/ Kasım 1535). VDA, Documenti Turchi, Busta 7, s. 1, fasc. 28, Pezzi 3 (Gökbilgin 1964: 162-163).

\section{Kaynaklar}

\section{Venedik Devlet Arşivi}

Consiglio dei Dieci, Parti Secrete, Registro. 2, 52v-53r. Andrea Gritti'den Alvise Gritti'ye (18 Mart 1528).

Dispacci Degli Ambasciatori al Senato, Filza 1-A. Alvise Gritti'den Venedik Senatosu'na (4 Şubat 1526).

Ducali ed Atti Diplomatici, Busta 22. Andrea Gritti'den Alvise Gritti'ye (2 Kasım 1529, vd.).

\section{Başvuru Kaynakları}

Agoston, Gabor (2011). "Enformasyon, İdeoloji ve Emperyal Siyasetin Sınırları: Osmanlı-Habsburg Rekabeti Bağlamında Osmanlı Büyük (Grand) Stratejisi”. Erken Modern Osmanlılar: Imparatorluğun Yeniden Yazımı. Der. Virginia H 
Aksan, Daniel Goffman. İstanbul: Timaş Yay. 105-142.

Alberi, Eugenio (1840-1855). Relazioni degli Ambasciatori al Senato. C. 1, 3. Floransa.

Aydın, Bilgin (2007). "Divan-ı Hümayun Tercümanları ve Osmanlı Kültür ve Diplomasisindeki Yerleri”. Osmanlı Araştırmaları Dergisi 29: 41-86.

Atasoy, Nurhan (1972). İbrahim Paşa Sarayı. İstanbul: İ. Ü. Edebiyat Fakültesi Basimevi.

Barta, Gabor (2008). “Gritti Ludovicus'un Macar Valiliği (1531-1534).” Belleten 72 (263): 251-293.

Boone, Rebecca Ard (2016). Mercurino di Gattinara and the Creation of the Spanish Empire. Londra-New York: Routledge.

Celâlzâde Mustafa Celebi (2011) Tabakâtü̈l Memâlik ve Derecâtüll-Mesâlik: Kanunî̀nin Tarihçisinden Mubteşem Çă̆ Kanunî Sultan Süleyman. Haz. Ayhan Yilmaz. İstanbul: Kariyer Yay.

Celalzâde Salih Çelebi (2016) Târîh-i Sefer-i Zafer-Rehber-i Alaman [Kanunî Sultan Süleymanin Alaman Seferi(1532)]. Haz. Fatma Kaytaz. İstanbul: Çamlıca Yay.

Charrière Ernest. (1848-1860). Négociations de la France dans le Levant, ou, Correspondances, Mémoires et Actes Diplomatiques des Ambassadeurs de France à Constantinople et Des Ambassadeurs, Envoyés ou Résidents à Divers Titres à Venise, Raguse, Rome, Malte et Jérusalem, en Turquie, Perse, Géorgie, Crimée, Syrie, Egypte, etc., et Dans Les Etats de Tunis, d'Alger et de Maroc. c.1-4. Paris: Imprimerie Nationale.

Della Valle, Francesco (1857). "Una breve narracione della grandezza, virtù, valore et della infelice morte dell'Illustrissimo Signor Conte Alouise Gritti, del Serenissimo Signor Andrea Gritti, Principe di Venezia, Conte del gran Contado di Marmarus in Ongaria et General Capitano dell'esercito Regno, appresso Sulimano Imperator de Turchi, et alla Maesta del Re Giovanni Re d'Ongaria”. Magyar Történelmi Tár. Der. Iván Nagy v. 3 Peşte: 9-60.

Emecen, Feridun (2000). "İbrahim Paşa, Makbul”. TDV İslam Ansiklopedisi. C. 21. İstanbul: TDV Yay. 333-335.

Finlay, Robert (1998). "Prophecy and Politics in Istanbul: Charles V, Sultan Suleyman, and the Habsburg Embassy of 1533-1534". Journal of Early Modern History 2 (1): 1-31.

Finlay, Robert (2000). "Fabius Maximus in Venice: Doge Andrea Gritti, the War of Cambrai and the Rise of Habsburg Hegemony, 1509-1530". Renaissance Quarterly 53 (4): 988-1031.

Fodor, Pal (1991). "Ottoman Policy Towards Hungary, 1520-1541". Acta Orientalia Academiae Hungaricae 45 (2/3): 271-345.

Gelibolulu Mustafa Âlî (2009) Künhüll Ahbâr. Dördüncü Rükn. Ankara: TTK Yay.

Gökbilgin, Tayyib M. (1952). "İbrâhîm Paşa, Pargalı, Frenk, Makbûl, Maktûl”. İslam Ansiklopedisi. C. 2. http://tayyibgokbilgin.info/ansiklopedisi/ (Erişim Tarihi: 26.04.2016).

Gökbilgin, Tayyib M. (1964). "Venedik Devlet Arşivindeki Vesikalar Külliyatında Kanunî Sultan Süleyman Devri Belgeleri”. Belgeler 1 (2): 119-220.

Gökbilgin, Tayyib M. (1968-1971). "Venedik Devlet Arşivindeki Türkçe Belgeler Koleksiyonu ve Bizimle İlgili Diğer Belgeler”. Belgeler 5-7 (9-12): 1-152.

Gökbilgin, Tayyib M. (2001). "Kanuni Sultan Süleyman'ın Macaristan ve Avrupa 
Siyaseti’nin Sebep ve Âmilleri”. Kanunî Armağanı. Ankara: TTK Yay. 5-41. Gürkan, Emrah Safa (2011). "Osmanlı-Habsburg Rekâbeti Çerçevesinde Osmanlılar’ın XVI. Yüzyıl'daki Akdeniz Siyaseti”. Osmanlı Dönemi Akdeniz Dünyası. Haz. Haydar Çoruh, M. Yaşar Ertaş, M. Ziya Köse. İstanbul: Yeditepe Yay. $11-50$.

Isom-Verhaaren, Christine (2011) Allies with the Infidel: The Ottoman and French Alliance in the Sixteenth Century. New York: I.B. Tauris \&Co Ltd.

İnalcık, Halil (2001) "Avrupa Devletler Sistemi, Fransa ve Osmanlı: Avrupa'da Geleneksel Dostumuz Fransa Tarihine Ait Bir Olay”. Doğu Batı 14: 122-142.

İnalcık, Halil (2009). Devlet-i Aliyye: Osmanlı İmparatorluğu Üzerine Araştırmalar-I. İstanbul: Türkiye İş Bankası Kültür Yay.

Jenkins, Hester Donaldson (1911). Ibrahim Pasha: Grand Vizir of Suleiman the Magnificent. New York: Columbia University Press.

Kumrular, Özlem (2007). “Orta Avrupa’nın Kaderini Değiştiren Savaş: Mohaç Öncesi ve Sonrası ve Kastilya'da Yankısı”. Belleten 71 (261): 537-574.

Kurz, Otto (1969). "A Gold Helmet Made in Venice for Sultan Sulayman the Magnificent". Gazette des Deaux-Arts Annê" 84 (111): 249-258.

Necipoğlu, Gülru (1989). "Süleyman the Magnificient and the Representation of Power in the Context of Ottoman-Habsburg-Papal Rivalry". The Art Bulletin 71 (3): 401-427.

Otman, Elvin (2012). "Beyoğlu’nda Bir "Bey Oğlu”: Alvise Gritti”. İstanbul Araştırmaları Yillığı 1: 127-144.

Paruta, Paolo (1703). Historia Vinetiana. Venedik.

Peçevî İbrahim Efendi (1980). Târih-i Peçevî. İstanbul: Enderun Kitabevi.

Ramberti, Benedetto (1539). Libri Tre Delle Cose de Turchi. Venedik.

Rice, Eugene and Anthony Grafton (1994). The Foundations of Early Modern Europe, 1460-1559. New York: W. W. Norton \& Company, Inc.

Sanuto, Marino (1879-1903). I Diarii. Der. Rinaldo Fulin. C. 35. Bolonya: Forni Editore.

Szakaly, Ferenc (1995). Lodovico Gritti in Hungary 1529-1534: A Historical Insight into the Beginnings of Turco-Habsburgian Rivalry. Budapest: Akademiai Kiado.

Tezcan, Esma (2004). Pargalı İbrahim Paşa Çevresindeki Edebi Yaşam. Yüksek Lisans Tezi. Ankara: Bilkent Üniversitesi.

Turan, Ebru (2007). The Sultan's Favorite: İbrahim Pasha and the Making of the Ottoman Universal Sovereignity in the Reign of Sultan Süleyman (1516-1526). Doktora Tezi. Chicago Üniversitesi.

Turan, Ebru (2009). "The Marriage of İbrahim Pasha (ca. 1495-1536): The Rise of Sultan Süleyman's Favorite to the Grand Vizierate and the Politics of the Elites in the Early Sixteenth-century Ottoman Empire”. Turcica 41: 3-36.

Uzunçarşıll, İsmail Hakkı (1998). Osmanlı Tarihi. C. 2. Ankara: TTK Yay.

Zinkeisen, Johann Wilhelm (2011). Osmanlı Imparatorluğu Tarihi. C.2 Çev. Nilüfer Epeçli. İstanbul: Yeditepe Yay. 


\title{
The Relations Between The Ottoman Empire and The Republic of Venice within The Framework of International Balances and Grand Vizier Ibrahim Pasha (1523-1536)*
}

\section{Elvin Otman **}

\begin{abstract}
During the Grand Vizierate of İbrahim Pasha, decisively shaping Ottoman international policy during the reign of Kanunî Sultan Süleyman, the diplomatic relations between the Ottoman Empire and Republic of Venice were strengthened. In the scope of the Ottoman-Habsburg political, military and ideological rivalry, the Republic was perceived both as an ally and source of information. In this period, an open war between the states was never experienced. However, following the 1532 German Expedition, a rapprochement between Venice and the Habsburg Emperor changed the Ottoman approach towards Venice and İbrahim Pasha often warned the Republic to act according to the ahidname rules. The Venetian documents of the period, in which he was defined as the friend of Venice, displays that Pasha adopted a tough policy toward the Republic in his last years in the grand vizierate. This article argues that the OttomanVenetian relations in the mentioned period was basically shaped by the changing international balances and İbrahim Pasha was the most influential political character both editing the international policies and balancing the OttomanVenetian relations. The Ottoman expedition to Corfu Island of Venice following his death in 1536, proves this argument.
\end{abstract}

\section{Keywords}

İbrahim Pasha (v. 1523-1536), Venice, Ottoman-Habsburg rivalry, Charles Quint, Alvise Gritti, universal sovereignty, Relazione.

\footnotetext{
Date of Arrival: 27 June 2016 - Date of Acceptance: 31 January 2017

You can refer to this article as follows:

Otman, Elvin (2019). "Uluslararası Dengeler Çerçevesinde Osmanlı İmparatorluğu-Venedik Cumhuriyeti İlişkileri ve Sadrazam İbrahim Paşa (1523-1536)". bilig-Journal of Social Sciences of the Turkic World 90: $137-160$.

" Dr., Ankara/Turkey ORCID ID: https://orcid.org/0000-0003-3558-9567 elvinotman@gmail.com
} 


\section{Османская империя и Венецианская республика в контексте мирового соперничества и садразам Ибрагим-паша $(1523-1536)^{*}$}

\section{Эльвин Отман}

\section{Аннотация}

При садразаме Ибрагим-паше, которому принадлежала решающая роль в международной политики Османской империи во время правления Сулеймана Законодателя, дипломатические отношения между Османской империей и Венецианской республикой были укреплены. В контексте османско-габсбургского политического, военного и идеологического соперничества Республика воспринималась как союзник и источник информации.

В этот период не происходило открытых столкновений между государствами. Однако после военного похода Сулеймана Великолепного 1532 года сближение между Венецией и императором Габсбургов изменило османский подход к Венеции, и Ибрагим-паша неоднократно предупреждал Республику о необходимости действовать в соответствии с правилами существующего соглашения (ахиднаме).

Венецианские документы того периода, в которых он фигурирует как друг Венеции, свидетельствуют о том, что Паша в последние годы в должности великого визира проводил жесткую политику в отношении Республики. В этой статье утверждается, что османсковенецианские отношения в указанный период определялись в основном изменяющимися международными балансами, и Ибрагимпаша был наиболее влиятельным политическим персонажем, который влиял на международную политику и на баланс османсковенецианских отношений. Нарушение османско-венецианских мирных договоренностей после османской высадки на подвластный Венеции остров Корфу, состоявшейся после смерти Ибрагим-паши в 1536 году, подтверждает это положение.

\section{Ключевые слова}

Ибрагим-паша (садразам, 1523-1536), Венеция, соперничество Османской империи и Габсбургов, Карл V Габсбург, Альвизе Гритти, мировая империя, Relazione.

\footnotetext{
Поступило в редакцию: 27 июня 2016 г. - Принято в номер: 31 января 2017 г.

Ссылка на статью:

Otman, Elvin (2019). "Uluslararası Dengeler Çerçevesinde Osmanlı İmparatorluğu-Venedik Cumhuriyeti İlişkileri ve Sadrazam İbrahim Paşa (1523-1536)”. bilig - Журнал Гуманитарных Наук Тюркского Мира 90: 137-160.

** Д-р, Анкара / Турция

ORCID ID: https://orcid.org/0000-0003-3558-9567

elvinotman@gmail.com
} 